\title{
SOME RARE HETEROPTERA SPECIES (HEMIPTERA) FROM THE „COBÎLENI” NATURAL RESERVE, REPUBLIC OF MOLDOVA
}

\author{
Valeriu Derjanschi \\ Institute of Zoology, Chişinău, Republic of Moldova, e-mail: valder2002@yahoo.com
}

Abstract. A list of the some rare heteroptera species from the „Cobîleni” Natural Reserve is published. The list contains 9 species from 5 families: Corixidae (3 species), Anthocoridae (1), Miridae (3), Lygaeidae (1) and Pentatomidae - 1 species. Data on bio-ecology and host plants are given. It is noted that the „Cobîleni” Reserve are the guarantor of the preservation of both typical biotopes and rare and endangered species of true bugs.

\section{Introduction}

The suborder Heteroptera (Hemiptera) is one of the most studied groups on the territory of the Republic of Moldova $[2,3,4,5,6,7,8,9,10]$. At the same time, many species of bugs from the local fauna are rare. Due to the changing habitat, some species of true bugs are on the verge of extinction. The reserves are the only guarantor of the preservation of both typical biotopes (of a particular zone of the Republic of Moldova) and some rare and endangered species of insects.

\section{Material and methods}

The researches were carried out during the vegetation period of 2016-2018 in the „Cobîleni” Nature Reserve $\left(47^{\circ} 30^{\prime} 51^{\prime \prime} \mathrm{N}, 2^{\circ} 01^{\prime} 20^{\prime \prime} \mathrm{E}\right)$ located near Lopatna village (Orhei District) on the right bank of the Dniester river. The „Cobîleni” reservation is a natural forest area, with an area of 33.5 ha, it belongs to the Susleni Forest District (fig. 1).
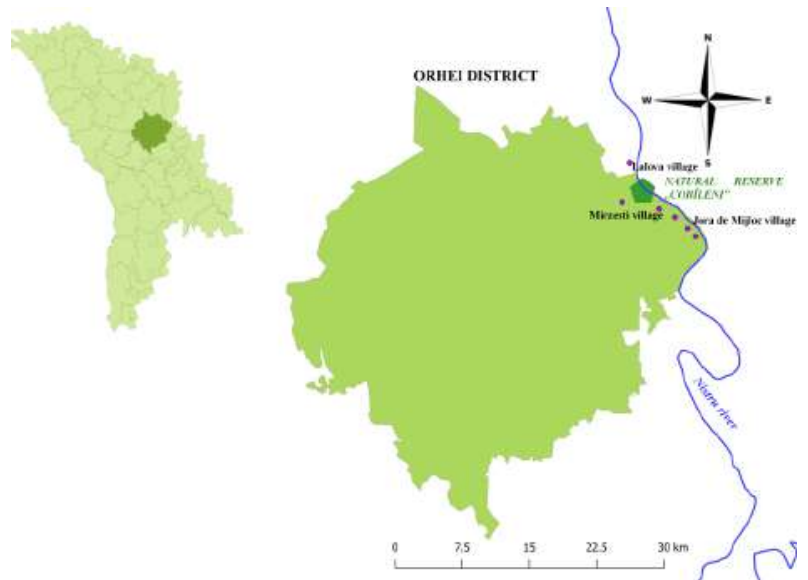

Figure 1. The location schematic map of „Cobîleni” Natural Reserve, Orhei District, Republic of Moldova [19]

The territory of the "Cobîleni” Reserve is located on the right bank of the Dniester and its terraces. In the Reserve there are biotopes with floodplain vegetation, forest and stony steppe 
sectors. The rock forest, specific to the steep slopes of the Dniester valley is formed by Quercus robur and Fraxinus excelsior. The steep sectors in the center of the Reserve, facing east, contain Stipa pulcherrima, Amygdalus nana, Rhamnus cathartica, Thalictrum minus, Silene fabaria and others. Numerous species of ferns, mosses, lichens (Cladonia pyxidata, C. fimbriata, etc.) and some angiosperms grow on the limestone rocks of the Dniester valley, which together form a mosaic similar to that of mountainous areas [19].

In the present investigations there were used field collectings from different biotopes. The true bugs were collected using usual entomological methods. Also in our studies, light traps with white and ultraviolet lamps were used.

\section{Results and discussions}

As a result of research, 9 rare species of true bugs were registered on the territory of the „Cobîleni” Reserve. These species belong taxonomically to 5 families: Corixidae - Corixa affinis Leach, Hesperocorixa sahlbergi Fieb., Sigara iactans Janss.; Anthocoridae - Amphiareus obscuriceps Popp.; Miridae - Hallodapus suturalis H.-S., Pilophorus cinnamopterus Kirschbm., Psallopsis neglecta Konst.; Lygaeidae - Peritrechus meridionalis Put. and Pentatomidae - Clorochroa pinicola Mls. \& Rey.

In the list of heteroptera species shown below, are presented the date of collection, number of caught specimens, geographical spread and bio-ecological peculiarities.

\section{CORIXIDAE Family}

\section{Corixa affinis Leach, 1817}

Material: Two males captured July 5, 2016 on the ultraviolet light trap near the Dniester river.

Bioecology: Brackish ditches and pools, mostly near the coasts of central and southern England and Wales [1]. There is also evidence that the species prefers stagnant water [14]. Probably, a general increase in temperature provokes an increase in the concentration of salts in water, which contributes to the spread of hallophilic species.

Distribution: Holomediterranean species [16]. Is present in the countries of Central and Southern Europe, Northern Africa, Turkey, Iran, Iraq, Caucasus, south of european part of Russia, Kazakhstan, Turkmenistan, Uzbekistan and Tajikistan (to the Amu Darya river), north of India.

\section{Hesperocorixa sahlbergi (Fieber, 1848)}

Material: One male was caught July 19, 2017 in a light trap with an ultraviolet lamp in the „Cobîleni“" Reserve.

Bioecology: In England this very common species occurs in densely vegetated ponds and lakes, which have a bed o f dead leaves or mud. In the meres it is confined to pools and ditches in the fringing Alder woods [12].

The Hesperocorixa sahlbergi found in ponds, ditches, lake margins and neglected aquatic habitats especially with dead vegetation. The overwinters adults mate in early spring when the water is still quite cold and the resulting nymphs take at least two months to develop into adults.

Distribution: This species is widespread in Europe, Caucasus, Eastern and Western Siberia. 


\section{Sigara iactans Jansson, 1983}

Material: From the „Cobîleni“ Reserve total in the period June, 13 - September 19, 20162018 was collected 64 specimens.

Bioecology: The species seems to seek permanent water bodies, mesotrophic to eutrophic, which have little submerged aquatic vegetation with a $\mathrm{pH}$ greater than or equal to 7 . If it can withstand weakly flowing waters, however it prefers lentic waters soft and brackish dunes. In its stations, it is most often found in company of Sigara falleni (Fieber, 1848), very rarely alone [11].

Distribution: Central and south-eastern part of Europe. On the territory of the Republic of Moldova, this species, until recently, was mixed with Sigara falleni Fieb. morphologically similar to it; therefore, all previous records should be reviewed. Our data indicate a more northern confinement of this species in the Republic of Moldova [8].

\section{ANTHOCORIDAE Family}

Amphiareus obscuriceps (Poppius, 1909)

Material: Total in the period June, 4 - September 25, 2016-2018 in the „Cobîleni“ Reserve was collected almost 300 specimens of this species.

Bioecology: As habitat for A. obscuriceps can by different open areas and woodlands, associated with dead-leaf habitats in the trees or on the ground, also brush piles and old tent of caterpillar nests. The minute pirate bugs feed on small arthropods, probably including aphids, thrips, etc.

Distribution: Is considered native to Asia, recently introduced to North America (has spread across the eastern half of the US \& Canada) and Europe [13].

\section{MIRIDAE Family}

Hallodapus suturalis (Herrich-Schäffer, 1837)

Material: July 13, September 17, 2016, 2 specs. (to the ultraviolet light).

Bioecology: Apparently, he lives in rocky areas of the Reserve, under grassy vegetation. It feeds on sap on the roots of various steppe plants.

Distribution: Southern part of Europe, North Africa, Turkey, Caucasus, Central Asia.

Pilophorus cinnamopterus (Kirschbaum, 1856)

Material: Total in the period June, 17 -September 27, 2016-2017 was collected on the white light 14 specs. and 21 specs. - on the ultraviolet light.

Bioecology: In the Reserve was noted on a pine tree (Pinus nigra), among a colony of aphids from the genus Cinara.

Distribution: Widespread in all Europe, Caucasus (Azerbaijan), Asian part of Turkey, Eastern Siberia.

\section{Psallopsis neglecta Konstantinov, 1998}

Material: August 17, 23, September 3, 2016, 4 specs.

Bioecology: According to F. Konstantinov [15] the host plants not clarified, but certainly annual Chenopodiaceae. Some specimens from collections are labelled as collected from annual Suaeda, Halogeton and Petrosimonia. 
Distribution: Ukraine, south of European part of Russia, Kazakhstan, Uzbekistan, West Siberia and Mongolia.

\section{LYGAEIDAE Family}

\section{Peritrechus meridionalis Puton, 1877}

Material: August 5,7, 2016, 2 specs. (to the white light).

Bioecology: Most often noted under plants from genera Suaeda, Salicornia and Puccinellia [17].

Distribution: South and south-east Europe, Caucasus, South-West and Central Asia, North Africa [4].

\section{PENTATOMIDAE Family}

Clorochroa pinicola (Mulsant \& Rey, 1852)

Material: August 7, 2016, 1 spec., on Pinus nigra.

Bioecology: This species lives and feeds on pine trees (Pinus spp.), but can also be found on Abies alba and Juniperus communis. Hibernates in the adult stage. Has one generation per year. [18].

Distribution: Europe (except United Kingdom Island), Caucasus, Kazakhstan, West Siberia.

The research was carried in the project 20.80009.7007.02. from the State program at the Institute of Zoology.

\section{Conclusions}

Thus, in various biotopes of the "Cobîleni” Natural Reserve, 9 rare species of true bugs from 5 families were registered: Corixidae - Corixa affinis Leach, Hesperocorixa sahlbergi Fieb., Sigara iactans Janss.; Anthocoridae - Amphiareus obscuriceps Popp.; Miridae - Hallodapus suturalis H.-S., Pilophorus cinnamopterus Kirschbm., Psallopsis neglecta Konst.; Lygaeidae - Peritrechus meridionalis Put. and Pentatomidae - Clorochroa pinicola Mls. \& Rey. For each species data on bio-ecology and host plants are given.

Our research has shown that the „Cobîleni” Reserve are the guarantor of the preservation of both typical biotopes and some rare and endangered species of true bugs.

\section{Bibliography}

1. Cook A. A. 2015. A review of the Hemiptera of Great Britain: The aquatic and semi- aquatic bugs. Natural England Commissioned Report NECR188, no. 24: 61 pp.

2. Derzhansky V. 1997. List of the Heteroptera of the Republic of Moldova. St.-Petersburg. 22 pp.

3. Derjanschi V. 2007. Tigrul platanului Corythucha ciliata Say (Heteroptera, Tingidae) - specie nouă pentru fauna Republicii Moldova. Muzeul Naţional de Etnografie şi Istorie Naturală. Buletin ştiinţific. Ştiinţele Naturii (serie nouă), Chişinău. 6(19): 46-47.

4. Derjanschi V. 2010. Additional data to the fauna of heteroptera (Insecta, Hemiptera) from the Republic of Moldova. Muzeul Olteniei, Craiova. Studii şi comunicări. Ştiinţele naturii, Craiova. 26(1): 109-110.

5. Derjanschi V. 2013. First record of Arocatus longiceps Stål. (Heteroptera, Lygaeidae) for the Republic of Moldova. Actual problems of protection and sustainable use of the animal world diversity. VIII-th International Conference of Zoologists, 10-12 October 2013. Book of Abstract. Edit. Elan Poligraf, Chișinău: 123-124. 
6. Derjanschi V. 2016. Orthops forelii Fieber 1858 (Heteroptera, Miridae) - new species in the fauna of the Republic of Moldova. Sustainable use, protection of animal world and forest management in the context of climate change. Materials of the IX-th International Conference of Zoologists, 12-13 October, Chisinau. Book of Abstract. Edit. Elan Poligraf, Chișinău: 122.

7. Derjanschi V., Chimişliu Cornelia. 2019. Ploşniţa marmorată Halyomorpha halys (Stål, 1855) (Heteroptera, Pentatomidae) - specie alogenă invazivă nouă în fauna Republicii Moldova. Muzeul Naţional de Etnografie şi Istorie Naturală. Buletin ştiinţific. Ştiinţele Naturii (serie nouă), Chişinău. 30(43): 18-22.

8. Derjanschi V., Chiriac I. 2020. New and less known true bug species (Hemiptera: Heteroptera) in the fauna of the Republic of Moldova. Muzeul Olteniei Craiova. Oltenia. Studii şi comunicări. Ştiinţele Naturii. Craiova. 36(2): 70-74.

9. Derjanschi V., Matocq A. 2005. Contribuţii la cunoaşterea faunei heteropterelor (Insecta, Hemiptera) din Republica Moldova. Analele Ştiinţifice ale Universităţii de Stat din Moldova. Seria "Ştiințe chimico-biologice", Chişinău: 182-183.

10. Derjanschi V., Mocreac Nadia. 2018. Tigrul stejarului Corythucha arcuata (Say, 1832) (Heteroptera, Tingidae) - specie nouă invazivă în fauna Republicii Moldova. Muzeul Naţional de Etnografie şi Istorie Naturală. Buletin ştiinţific. Ştiinţele Naturii (serie nouă), Chişinău. 28(41): 30-35.

11. Elder J.-F., Chéreau L. 2003. Une nouvelle espèce d'Hydrocorise pour la faune de France: Sigara (Subsigara) iactans Jansson, 1983 (Heteroptera, Corixidae). Bulletin de la Société entomologique de France, 108(4): 405-407.

12. Guest J. P., Savage A. A. \& Wallace I. D. 2003. The freshwater bugs (Hemiptera: Heteroptera) of Cheshire. Journal of the Lancashire \& Cheshire Entomological Society, 127: 10-22.

13. Henry T. J., Wheeler A. G. and Steiner W. E. 2008. Proceedings of the Entomological Society of Washington, 110: 402-416.

14. Kanyukova E. V. 2006. Aquatic and semi-aquatic bugs (Heteroptera: Nepomorpha, Gerromorpha) of the fauna of Russia and neighbouring countries. Edit. Dalnauka, Vladivostok. 297 pp.

15. Konstantinov F.V. 1997. A revision of the genus Psallopsis (Heteroptera: Miridae). Zoosystematica Rossica, St.-Petersburg, 6(1/2): 171-190.

16. Linnavuori R. E. 1994. Hemiptera of Iraq. IV. Heteroptera, the aquatic and subaquatic families, Saldidae and Leptopodidae. In: Entomologica Fennica, 5: 87-95.

17. Pericart J. 1998. Hémiptères Lygaeidae euro-méditerranéens. Vol. 3. Edit. Faune de France, Paris. 487 pp.

18. Ribes J., Pagola-Carte S. 2013. Hemipteres Pentatomoidea Euro-Mediterraneens. V. 96 (2). Edit. Faune de France, Paris, 423 pp.

19. Țugulea Cr., Țugulea A. 2020. Cucullia fraterna Butler, 1878 (Lepidoptera, Noctuidae) - a new species in the fauna of the Republic of Moldova. Muzeul Olteniei Craiova. Oltenia. Studii şi comunicări. Ştiinţele Naturii. Craiova. 36(1): 96-99. 